\title{
DETERMINAÇ̃̃o DOS VALORES DO ÁCIDO SIÁLICO NO SANGUE DE FÊMEAS SADIAS DA RAÇA NELORE CRIADAS NO NORTE DO PARANÁ
}

\author{
Marcos Coelho Carvalho ${ }^{1}$, Wilmar Sachetin Marçal ${ }^{1}$, Mara Stipp Balarin ${ }^{1}$, Nelson \\ Parizotto Junior ${ }^{\uparrow}$
}

1 Universidade Estadual de Londrina-UEL.

Endereço para correspondência: Nelson Parizotto Junior: nelsonpjunior@yahoo.com.br

\begin{abstract}
RESUMO: Os marcadores tumorais e inflamatórios são substâncias encontradas no sangue, urina ou tecidos de pessoas e/ou animais com certos tipos de neoplasias ou inflamações crônicas. A utilização de alguns destes marcadores químicos, como o ácido siálico, poderá ser uma importante ferramenta no auxílio diagnóstico de enfermidade que acometem os animais de produção, em especial os bovinos. Neste contexto, realizou-se um ensaio com o objetivo de mensurar o referido marcador inflamatório e verificar os valores normais no sangue de fêmeas sadias da raça Nelore criadas no Norte do Paraná. Avaliou-se20 bezerras, 19 novilhas e 20 vacas através da punção da veia coccígea, e análise do soro utilizando o método tiobarbitúrico, com leitura posterior em Espectrofotômetro de Duplo Feixe Termoestatizado. Os níveis séricos médiosnas diferentes categorias foram de $0,740 \pm 0,311 \mathrm{~g} / \mathrm{L}, 0,611 \pm 0,225 \mathrm{~g} / \mathrm{L}$ e 0,591 $\pm 0,236 \mathrm{~g} / \mathrm{L}$ para bezerras, novilhas e vacas, respectivamente. Os valores de ácido siálico encontrados em bezerras Nelore saudáveis foram próximos aos descritos na literatura mundial. Porém, nas vacas e nas novilhas sadias, obtiveram-se médias inferiores, sugerindo que nos Nelores adultos e saudáveis os níveis do ácido siálico são menores, quando comparados a outras raças européias leiteiras.
\end{abstract}

Palavras-chave: marcadores bioquímicos; bovinos; valores normais.

\section{DETERMINATION OF VALUES OF THE SIALIC ACID IN THE BLOOD OF HEALTHY FEMALES OF NELORE BREED RAISED IN NORTH PARANÁ}

\begin{abstract}
The tumoral and inflammatory markers are substances found in the blood, urine or tissues of people and/or animals with certain types of neoplastics or chronic inflammations. The use of some biochemical markers as the sialic acid, could be an important tool to aid in the diagnosis of diseases that affect livestock, especially bovine. In this context, an assay was carried out to standardize and determine the normal values of sialic acid concentrations in blood of clinically health Nelore femalesraised in north Paraná. It was evaluated in 20 calves, 19 heifers and 20 cows by coccygeal venipuncture, and serum analysis using the thiobarbituric method, with further reading on Spectrophotometer. The average serum sialic acid concentrations in the different categories were $0,740 \pm 0,311 \mathrm{~g} / \mathrm{L} ; 0,611 \pm 0,225 \mathrm{~g} / \mathrm{L}$ and $0,591 \pm 0,236 \mathrm{~g} / \mathrm{L}$ for calves, heifers and cows, respectively. The values of sialic acid found in healthy Nelore heifers were close to described ones in the world literature. However in the cows and in the heifers medium minors were obtained, suggesting that in the healthy adult Nelores the levels of the sialic acid are mean, when compared to other Bos taurus breeds.
\end{abstract}

Key Words: biochemical markers; bovine; normal values. 


\section{INTRODUÇÃO}

Marcadores tumorais e/ou inflamatórios são substâncias encontradas no sangue, urina ou tecidos dos animais com certo tipo de neoplasias. A maioria dos marcadores tumorais são proteínas ou fragmentos de proteínas. Eles são produzidos pelo próprio tumor ou pelo organismo como resposta à inflamação ou presença do câncer (MILLER et al., 1978).

A utilização de biomarcadores no diagnóstico e no controle pós-operatório de neoplasias na espécie humana, já vem sendo utilizada de forma rotineira há anos. Tem-se verificado também, um aumento crescente de publicações dessa linha de pesquisa na medicina veterinária de animais de companhia, porém, esta tecnologia de diagnóstico ainda está pouco difundida para animais de produção.

Dentre os carboidratos presentes nos glicoconjugados de membrana destacam-se os ácidos siálicos, uma família de carboidratos complexos de nove carbonos, normalmente ligados a outros carboidratos por meio de ligações cetosídicas (KATOPODISet al., 1982). Localizados nas posições terminais de glicoconjugados da superfície celular, os ácidos siálicos estão intimamente envolvidos em processos biológicos fundamentais à manutenção da vida, mas em funções diferentes daquelas normalmente atribuídas a carboidratos como armazenadores de energia (glicogênio e amido, por exemplo) ou como componentes de blocos estruturais (quitina e celulose). Como exemplos do envolvimento dos ácidos siálicos em processos biológicos incluem-se as funções de mediadores na adesão célula-célula, mediadores na comunicação intercelular, renovadores celulares, receptores para bactérias e vírus, entre outras (WILSON; VON ITZSTEIN, 2003; SEARS; WONG, 1999).
Trabalho conduzido por Singh et al. (1980) demonstrou a possibilidade de alta correlação entre a produção excessiva de mucoproteína nos animais com tumor de bexiga e o ácido siálico, embora Carvalho et al.(2011) e Camargo et al. (2008) tenham demonstrado que o ácido siálico não foi significativo ao comparar grupos de animais com hematúria enzoótica dos bovinos a animais saudáveis.

Makimura e Usui destacaram a inter-relação entre o ácido siálico e o aumento de neutrófilos em bovinos acometidos por doenças inflamatórias. Manohar et al. (1993) comprovaram a elevada significância $(P<0,01)$ entre o ácido siálico total como também ligado a lipídios com 0 carcinoma etmoidal em bovinos, provando que o ácido siálico é uma substancia importante no processo inflamatório e no desenvolvimento tumoral.

Ensaios conduzidos por Citil et al. (2004) e Gunes et al. (2004) comprovaram, respectivamente a evolução sérica do ácido siálico como um marcador inflamatório em bovinos com reticuloperitonite traumática e os níveis do mesmo em bezerros com lesões oculares causadas pela ceratoconjuntivite infecciosa bovina.

Por essas e outras interações positivas e negativas envolvendo 0 ácido siálico, hoje o aperfeiçoamento de técnicas de mensuração rápida desse açúcar e a adaptaçãoda técnica de extração do ácido siálico dos soros sanguíneos dos bovinos criados no Estado do Paraná é um passo importante na busca do diagnóstico precoce para moléstias neoplásicas ou inflamatórias crônicas que acometem essa e outras espécies de animais.

\section{MATERIAL E MÉTODOS}

Como suporte para a pesquisa de verificação do nível de ácido siálico no 
Determinação dos valores do ácido siálico no sangue de fêmeas sadias da raça nelore

soro sanguíneo de bovinos sadios, procedeu-se um ensaio laboratorial da técnica para determinar o valor normal desse açúcar. Os animais selecionados foram fêmeas da raça Nelore, criadas a pasto na Fazenda Figueira, uma estação experimental da ESALQ (Escola Superior de Agricultura Luiz de Queiroz) localizada no município de Londrina Estado do Paraná com altitude de 585 metros, Latitude de 23०19'11"S Longitude de $51^{\circ} 09^{\prime} 12 " W$ (GUIA RODOVIÁRIO QUATRO RODAS, 2007).

A área total da propriedade é de 3686 hectares, sendo 2070 hectares de pastagem. A pastagem predominante é Panicum maximum cv Colonião, porém foram formadas novas áreas com Panicum maximum cv Tanzânia e Panicum maximum cv Mombaça, além de Brachiaria brizantha cv Marandu. Existem ainda pastos antigos com grande participação do Paspalum notatum (grama batatais), mas nunca foi verificada a presença de samambaia nas pastagens e nunca houve casos clínicos de hematúria na propriedade.

A fazenda detinha no período do experimento um rebanho de 5.576 cabeças, sendo que, 2.115 eram matrizes. O controle sanitário da propriedade érigoroso, por ser uma instituição voltada à pesquisa, portanto os animais são vacinados anualmente contra febre aftosa e clostridiose, sendo as bezerras vacinadas também contra brucelose. A vermifugação é feita uma vez ao ano no gado adulto e três vezes ao ano nos jovens.

Para a realização do
experimento, foram selecionadas fêmeas nas três fases distintas do desenvolvimento da raça, para isso coletou-se sangue de 20 bezerras (5 a 7 meses de idade); 19 novilhas (15 a 24 meses de idade) e 20 vacas (com mais que 36 meses de idade), todos os animais passaram por anamnese clínica e apresentavam ausência de febre, baixíssima carga ectoparasitária, hidratados, com movimentos ruminais e fezes normais, além de peso e tamanho adequados a sua idade.

O sangue para pesquisa do ácido siálico foi coletado da veia coccígea, por meio de agulhas descartáveis e tubos de vidro estéril. Os tubos possuíam gel separador de soro e no laboratório foram centrifugados a $3000 \mathrm{rpm}$, por cinco minutos para obtenção completa do soro.

O armazenamento do soro foi feito em tubos que foram alocados em freezer com temperatura próxima a $20^{\circ} \mathrm{C}$ até a análise laboratorial, realizada através do método do tiobarbitúrico, descrito por Warren (1959). As leiturasforam feitas pelo método de espectrofotometria, utilizando-se o equipamento Espectronic Hélios a Computadorizado Duplo Feixe Termoestatizado, pertencente ao Hospital Universitário em Londrina-PR.

Os dados obtidos no experimento foram submetidos a análise de variância e para comparação das médias foi realizado o teste de Tukey, determinouse também, o intervalo de confiança, utilizando-se para as análises 0 programa SAEG (1998).

\section{RESULTADOS E DISCUSSÃO}

As médias, desvios-padrão e intervalos de confiança obtidos estão apresentados na Tabela 1. 
Tabela Médias e desvios-padrão e intervalo

1 - de confiança do ácido siálico ( $\mathrm{g} / \mathrm{L})$ em vacas, novilhas e bezerras da raça Nelore clinicamente saudáveis.

\begin{tabular}{lcc}
\hline $\begin{array}{l}\text { Categoria } \\
\text { Animal }\end{array}$ & $\begin{array}{c}\text { Ácido } \\
\text { Siálico (g/L) }\end{array}$ & $\begin{array}{c}\text { Intervalo de } \\
\text { Confiança a } \\
\mathbf{9 5 \%}\end{array}$ \\
\hline Vacas & $0,591 \pm$ & $0,485-$ \\
& 0,236 & 0,696 \\
\hline Novilhas & $0,611 \pm$ & $0,510-$ \\
& 0,225 & 0,712 \\
\hline Bezerras & $0,740 \pm$ & $0,602-$ \\
& 0,311 & 0,880 \\
\hline Média geral & $0,648 \pm$ & $0,579-$ \\
& 0,265 & 0,717 \\
\hline Coeficiente de & $40,22 \%$ & \\
Variação & & \\
\hline (P=15.40\%) & & \\
& &
\end{tabular}

Os resultados encontrados na presente pesquisa demonstraram que 0 ácido siálico apresenta-se em maior quantidade no soro dos bovinos jovens quando comparado aos adultos. Conforme é observado, as bezerras apresentam concentração média de ácido siálico de $0,740 \pm 0,311 \mathrm{~g} / \mathrm{L}$, superior a média do ácido siálico do soro das vacas que é de 0,591 $\pm 0,236$ $\mathrm{g} / \mathrm{L}$. Apesar dessa diferença não ser significativa, atribui-se a ela dois fatores nutricional e crescimento. O leite ingerido pelas bezerras, por ser um alimento rico em ácido siálico, e ao fator crescimento, pelo fato do ácido siálico exercer papel importante no desenvolvimento cerebral conforme demonstram pesquisas realizadas por Tram et al., (1997). Quando observamos os valores do ácido siálico das 19 novilhas (categoria animal púbere) encontramos a média de 0,611 $\pm 0,225$ $\mathrm{g} / \mathrm{L}$, muito próximada média geral das três categorias composto por 59 animais de 0,648 $\pm 0,265 \mathrm{~g} / \mathrm{L}$.

Quando comparamos os valores encontrados em cada categoria da presente pesquisa com os valores descritos na literatura mundial, verificamos que as 20 bezerras apresentam valor médio de ácido siálico de $0,740 \mathrm{~g} / \mathrm{L}$, muito próximo ao valor encontrado no estudo realizado por Gunes et al., (2004) que verificaram, em 12 bezerras sadias da raça Pardo Suíço, o valor médio de ácido siálico total de $0,763 \mathrm{~g} / \mathrm{L}$.

Nas vacas Nelores clinicamente sadias obteve-se o valor médio de 0,591 $\mathrm{g} / \mathrm{L}$ de ácido siálico. Este valor foi inferior ao encontrado em dois artigos publicados por Citil et al. (2004) e Singh et al. (1980), que utilizaram como base de pesquisa animais clinicamente saudáveis, mas de raças leiteiras, sendo os valores respectivamente de 0,76 e 0,73 g/L de ácido siálico.

Esse resultado abre margem para novas discussões e hipóteses para explicar a possível diferença da concentração sérica do ácido siálico entre animais da raça Nelore, com aptidão para carne e animais Bostaurus de aptidão leiteira. Questionamentos surgem quanto às diferenças nutricionais existentes entre os grupos de animais. Hipóteses também são levantadas quanto às possíveis variações experimentais, existentes entre os trabalhos na mensuração do acido siálico, por exemplo, os equipamentos ou reagentes utilizados. Porém a influencia genética pode ser determinante, pela rusticidade e aptidão de produção de carne do Nelore. Qualquer que seja o motivo tal diferença merece ser desvendada com novas pesquisas, caso o ácido siálico venha mesmo mostrar-se eficiente no cumprimento do propósito de marcador tumoral e/ou inflamatório.

Esta perspectiva adquire maior margem para discussão quando observamos 0 resultado descrito no experimento de Manohar et al. (1993), que encontrou o valor de $0,60 \mathrm{~g} / \mathrm{L}$ de acido siálico total no sangue de vacas zebuínas, também clinicamente saudáveis criadas na Índia. Este valor é muito próximo ao encontrado na presente pesquisa $0,591 \mathrm{~g} / \mathrm{L}$. 
Determinação dos valores do ácido siálico no sangue de fêmeas sadias da raça nelore criadas no norte do paraná

Para futuros esclarecimentos
outras pesquisas poderão ser
conduzidas, mas a princípio o Nelore adulto contém menores níveis de ácido siálico na corrente sanguínea que outras raças, principalmente leiteiras, conforme base comparativa descritas na literatura mundial.

\section{CONCLUSÃO}

As vacas adultas da raça Nelore apresentaram valores de ácido siálico inferior aos das bezerras, apesar da diferença não ser significativa. Em um " $\mathrm{n}$ " de 59 animais saudáveis da raça Nelore, verificou-seo valor médio 0,648 $\mathrm{g} / \mathrm{L}$. Portantoesse valor é mais uma referência para futuros trabalhos envolvendo o ácido siálico em bovinos da raça Nelore criados a pasto, já que outros trabalhos similares apontam que vacas zebuínas apresentaram valores de $0,60 \mathrm{~g} / \mathrm{L}$, muito próximo ao encontrado nesta pesquisa.

\section{REFERÊNCIAS}

CAMARGO, M. I.; PARIZOTTO JUNIOR, N.; CARVALHO, M. C.; MARÇAL, W. S. Aferição da concentração sérica de ácido siálico em novilhas da raça Nelore expostas e não expostas à samambaia (Pteridium aquilinum). Semina: Ciências Agrarias, Londrina, v. 29, n. 2, p. 393398, 2008.

CARVALHO, M. C.; MARÇAL, W. S.; BALARIN, M. S.; FORTES, M. S.; PARIZOTTO JUNIOR, N.; CAMARGO, M. I. Avaliação bioquímica do acido siálico como biomarcador tumoral em novilhas criadas em propriedades endêmicas para hematúria enzoótica dos bovinos. Ciência Animal Brasileira, Goiânia, v. 12, n. 2, p. 306210, 2011.

CITIL, M.; GUNES, V.; KARAPEHLIVAN, M.; ATALAN, G.; MARASLI, S. Evaluation of serum siálico acid as an inflammation marker in cattle with traumatic reticulo peritonitis. Revue Médecine Vétérinaire, Toulouse, v. 155, n. 7, p. 389-392, 2004.
GUIA rodoviário quatro rodas. Disponível em: <http://www.guia4rodasrodoviariopro.com.br/oqu e.asp>. Acesso em: maio 2007.

GUNES, V.; KARAPEHLIVAN, M.; CITIL, M.; ATALAN, G.; MARASLI, S. Relationship between serum sialic acid levels and eye lesions in calves with infectious bovine keratoconjuntivitis. Revue Médecine Vétérinaire, Toulouse, v. 155, n. 10, p. 508-511, 2004.

KATOPODIS, N.; HIRSHAUT, Y.; GELLER, N. L.; STOCK, C. C. Lipid-associated sialic acid test for detection of human cancer. Cancer Research, Phildelphia, v. 42, n. 12, p. 52705275, 1982

MAKIMURA, S.; USUI, M. Correlation between haptoglobin and sialic acid or mucoprotein in diseased bovine serum. Japanese Journalof Veterinary Science, Tokyo, v. 52, n. 6, p. 12451250, 1990.

MANOHAR, B.M.; SUNDARARAJ, A.; NAGARAJAN, B.; SHANMUGAM, V. Biochemical markers in the diagnosis of ethmoid carcinoma in cattle. Indian Veterinary Journal, Madras, v. 70, n.1, p. 14-16, 1993.

MILLER, C. A.; WANG, P.; FLASHNER, M. Mechaism of arthrobacter sialophilus neuraminidase: the binding of substrates and transition-state analogs. Biochemical Biophysical Research Communication., Netherlands, v. 83, n. 4, p. 1479-1487, 1978.

TRAM, T. H.; BRAND MILLER, J. C.; McNEIL, Y.; McVEAGH, P. Sialic acid content of infant saliva: comparison of breast fed with formula fed infants. Arch. Dis. Chilhood, London, v.77, v.4, p.315-8, 1997.

SEARS, P.; WONG, C. H.; Carbohydrate mimetics: A new strategy for tackling the problem of carbohydrate-mediated biological recognition.Angewandte Chemie International Edition, Weinheim, v.38, n.16, p.2301-2324, 1999.

SINGH, A.K; JOSHI, H.C; RAY, S.N. Serum mucoprotein and sialic acid in enzootic bovine 
haematuria. Zentbl Vetmed Reihe, Berlin, v.27, n.8, p.678-681, 1980.

UNIVERSIDADE FEDERAL DE VIÇOSA. SAEG: Sistema de Análise Estatística e Genética, versão 8.1. Viçosa, 1998.

WARREN, L. The thiobarbituric acid assay of siálic acids. Journal of Biological Chemistry, Bethesda, v.234, n. 8, p.1971-1975, 1959.

WILSON, J. C.; VON ITZSTEIN, M. Recent strategies in the search for new anti-influenza therapies. Currents Drugs Targets, Oak Park, v. 4 , p. 389, 2003. 